\title{
Studies on the Effect of Integrated Nutrient Management on Growth, Flowering and Yield of Italian Aster (Aster amellus L.) cv. 'Purple Multipetal'
}

\author{
R. Krushnaiah*, M. Hanuman Nayak, P. Prasanth and D. Saidanaik \\ Department of Floriculture and Landscape Architecture, College of Horticulture, Sri Konda \\ Laxman Telangana State Horticulture University, Rajendranagar, \\ Hyderabad-500 030, Telangana, India \\ *Corresponding author
}

\section{A B S T R A C T}

The present investigation "Studies on the effect of integrated nutrient management on growth, flowering and yield of Italian aster (Aster amellus L.) cv. 'Purple Multipetal" was carried out at the Floricultural Research Station, (Agricultural Research Institute)

Keywords

Italian aster, INM, RDF, vermicompost, FYM, Azospirillum, PSB,

Growth, Flowering and yield

Article Info

Accepted:

10 September 2018

Available Online:

10 October 2018
Rajendranagar, Sri Konda Laxman Telangana State Horticultural University, Hyderabad during September 2017 to January 2018. The experiment was conducted in a Randomized Block Design with three replications and eight treatments. Among all treatments application of RDF 50\% + RDF 50\% through Vermicompost + Azospirillum + PSB ( $\left.\mathrm{T}_{7}\right)$ was found maximum plant height at $30(18.36 \mathrm{~cm}), 60(32.20 \mathrm{~cm}), 90(52.16 \mathrm{~cm})$ and 120 $(64.25 \mathrm{~cm})$ DAP, plant spread E-W $(17.23,28.36,30.52$ and $34.30 \mathrm{~cm}), \mathrm{N}-\mathrm{S}(14.33,26.63$, 29.46 and $33.4 \mathrm{~cm})$, number of leaves per plant $(15.20,45.06,81.02$ and 198.06) at 30,60, 90 and 120 DAP respectively and number of suckers per plant $(6.33,10.16$ and 15.46) at 60, 90 and 120 DAP respectively. Respect to flowering and yield parameters minimum number of days (69.66 days) taken to flower bud initiation and 50 percent flowering (81.73 days), maximum number of flowers per plant (300.33), number of flowers per spike (181.00) number of spikelets per spike (35.20), number of flower spikes per plant (4.20), number of flower spikes per plot (105.00), number of flower spikes per ha. (4.66 lakhs) was recorded in $\mathrm{T}_{7}$ (RDF 50\% + RDF 50\% through VC + Azo + PSB).

\section{Introduction}

Aster malleus L. commonly called as 'Italian aster' or 'daisy' is an upcoming new potential cut flower crop belonging to Asteraceae family. It is a plur annual flower crop grown in many parts of the world for cut flowers. In India, it is being grown for its attractive cut flowers around big cities which are widely used for interior decoration in vases and also for bouquet making. Gradually, it is gaining lot of popularity among consumers and catching the flower markets. The growing popularity of daisy in most of the major cities in India has led to its cultivation as cut flower. The wide spectrum of colour ranges (blues, purples, pinks and whites) available in Aster amellus L. Potentially exploited as gardens 
plant for colourful effect in herbaceous borders, bedding and pots in gardens and also as dried flowers for interior decoration and export.Integrated nutrient management play an important role for improving the soil structure, physico-chemical properties and flower yield. At present, these nutrients are supplied through chemical fertilizers. The indiscriminate and continuous use of chemical fertilizers has led to an imbalance of nutrients in soil which has adversely affected the soil health, affecting the yield and quality of the produce. Therefore, the use of organic manures and bio fertilizers along with the balance use of chemical fertilizers is known to improve physico-chemical and biological properties of soil, besides improving the efficiency of applied fertilizers as well as crop yield and quality.Keeping in view the need and importance, present investigation was undertaken tostudies on the effect of integrated nutrient management on growth, flowering and yield of Italian aster (Aster amellus L.) cv. 'Purple Multipetal'

\section{Materials and Methods}

The present investigation was carried out at Floricultural Research Station, ARI (Agricultural Research Institute) Rajendranagar, Sri Konda Laxman Telangana State Horticultural University, Hyderabad during September 2017 to January 2018. The experiment was conducted in a Randomized Block Design with three replications and eight treatments viz., $\mathrm{T}_{1} \quad(100 \% \mathrm{RDF}), \mathrm{T}_{2}$ (RDF $50 \%+\mathrm{RDF} 50 \%$ through $\mathrm{VC}$ ), $\mathrm{T}_{3}$ (RDF $50 \%$ $+\mathrm{RDF} 50 \%$ through $\mathrm{VC}+\mathrm{Azo}), \mathrm{T}_{4}(\mathrm{RDF}$ $50 \%+\mathrm{RDF} 50 \%$ through $\mathrm{VC}+\mathrm{PSB}), \mathrm{T}_{5}$ (RDF $50 \%+$ RDF $50 \%$ through FYM), $\mathrm{T}_{6}$ (RDF 50\% + RDF 50\% through FYM + PSB), $\mathrm{T}_{7}$ (RDF $50 \%+\mathrm{RDF} 50 \%$ through $\mathrm{VC}+\mathrm{Azo}$ $+\mathrm{PSB}), \mathrm{T}_{8}(\mathrm{RDF} 50 \%+\mathrm{RDF} 50 \%$ through $\mathrm{FYM}+\mathrm{Azo}+\mathrm{PSB})$. The observations on various parameters of vegetative and flowering were recorded at 30, 60, 90 and 120 days after planting.

\section{Observation on growth parameters}

\section{Plant height (cm)}

The height of the five randomly selected tagged plants was measured from the ground level to the tip of tallest branch of the plant and the average was worked out and expressed in centimeters.

\section{Plant spread (cm)}

The maximum horizontal spread of the plant was measured in centimetres.

i.e. $\mathrm{N}-\mathrm{S}$ and $\mathrm{E}-\mathrm{W}$ directions at each growth stage.

\section{Number of leaves per plant (No.)}

The total numbers of leaves produced in each plant at different growth stages were counted and average was worked out.

\section{Number of suckers per plant (No.)}

The number of suckers produced by each tagged plant was counted and their mean was calculated

\section{Observations on flowering and flower yield attribute}

\section{Number of days taken to flower initiation}

The number of days taken for commencement of flowering was recorded by counting the days from the date of planting to the date of appearance of first flower bud was counted as days taken to flower initiation.

\section{Days to 50 per cent flowering}

The number of days taken for 50 per cent of the plants to produce first flower in each plot was recorded by counting the days from the date of planting. 


\section{Number of flowers per plant}

Number of flowers from each harvest was counted till the final harvest from the selected plants. The average number of flowers per plant was worked out

\section{Number of flowers per spike}

Number of flowers produced in each spike was counted from the tagged plants and the average number of flowers per spike was worked out.

\section{Number of flower spikes per plant}

Number of flower spikes produced in each plant was counted from the tagged plants and the average number of flower spikes per plant was worked out.

\section{Number of spikelets per spike}

Number of spikelets produced in each main flower spike of the observation plants was counted and number of spikelets per flower spike was worked out.

\section{Spike yield per plot (spike no. /plot)}

Numbers of flower spike produced by the each plot were recorded at each harvest and the mean value was worked out.

\section{Spike yield per ha (spike no. / ha)}

This was worked out by totaling the number of flower spikes per hectare (in lakhs) recorded at each harvest from net plots.

\section{Results and Discussion}

The plant height differed significantly due to imposition of integrated nutrient management at all the growth stages. The maximum plant height $(18.36 \mathrm{~cm})$ at 30 days after planting
(DAP) was recorded in $\mathrm{T}_{7}(\mathrm{RDF} 50 \%+\mathrm{RDF}$ $50 \%$ through VC + Azo + PSB) it was on par with $\mathrm{T}_{8} \mathrm{RDF} 50 \%+\mathrm{RDF} 50 \%$ through FYM + Azo + PSB (17.43 cm). At 60 DAP, significantly the maximum plant height (32.20 $\mathrm{cm})$ was recorded in $\mathrm{T}_{7}$ followed by $\mathrm{T}_{8} \mathrm{RDF}$ $50 \%+$ RDF $50 \%$ through FYM + Azo + PSB $(29.72 \mathrm{~cm})$. At 90 and 120 DAP highest plant height $(52.16$ and $64.25 \mathrm{~cm})$ was recorded in $\mathrm{T}_{7}$ respectively. While, the lowest plant height was recorded in $\mathrm{T}_{5}$ RDF $50 \%+\mathrm{RDF} 50 \%$ through FYM (Table 2).

The maximum plant spread E-W (17.23, 28.36, 30.52 and $34.30 \mathrm{~cm}), \mathrm{N}-\mathrm{S}$ (14.33, 26.63, 29.46 and $33.4 \mathrm{~cm}$ ) was recorded in $\mathrm{T}_{7}$ (RDF 50\% + RDF 50\% through VC + Azo + PSB) at 30, 60, 90 and 120 DAP respectively. Minimum plant spread E-W (9.33, 18.60, 19.43 and $24.13 \mathrm{~cm}), \mathrm{N}-\mathrm{S}(8.50,19.40,22.53$, and $27.50 \mathrm{~cm}$ ) was recorded in $\mathrm{T}_{5} \mathrm{RDF} 50 \%+$ RDF $50 \%$ through FYM at 30, 60, 90 and 120 DAP respectively (Table 2 ).

Maximum number of leaves per plant (15.20, 45.06, 81.02 and 198.06) was recorded in $\mathrm{T}_{7}$ (RDF 50\% + RDF 50\% through VC + Azo + PSB) at 30, 60, 90 and 120 DAP respectively. Minimum number of leaves per plant (10.53, 45.06, 81.20 and 198.06) was recorded in $\mathrm{T}_{5}$ (RDF $50 \%+$ RDF $50 \%$ through FYM) at 30, 60, 90 and 120 DAP respectively (Table 1).

Maximum number of suckers per plant (6.33, 10.16 and 15.46) was recorded in $\mathrm{T}_{7}$ (RDF $50 \%+$ RDF $50 \%$ through VC + Azo + PSB) at 60, 90 and 120 DAP respectively. At 60 and 90 DAP the minimum number of suckers per plant (1.16 and 6.50) was recorded in $\mathrm{T}_{5}(\mathrm{RDF}$ $50 \%+$ RDF $50 \%$ through FYM), which was on par with $\mathrm{T}_{2}$ (RDF $50 \%+\mathrm{RDF} 50 \%$ through $\mathrm{VC})$. At 120 DAP the minimum number of suckers per plant (10.06) was recorded in $\mathrm{T}_{5}$ (RDF $50 \%+$ RDF $50 \%$ through FYM) (Table 2). 
Combined application of inorganic, organic and biofertilizers enhances the plant height, plant spread, number of leaves per plant and number suckers per plant. Azospirillum fixes the atmospheric nitrogen and PSB mobilize phosphorous making these elements available for plant growth and development. Azospirillum secretes certain growth promoting substances like auxin, gibberellins, vitamins and organic acids which improve the growth. Whereas, PSB has ability to fix higher dose of phosphorous which stimulate root growth and enhances the absorption of nutrients and continuous supply and uptake of nutrients with higher moisture content thus resulting vigorous growth and enhances the number suckers per plant (Swati et al., 2017). Similar results were recorded by Yathindra $e t$ al., (2016) in Bird of paradise and Palagani et al., (2013) in chrysanthemum.

Table.1 Number of leaves per plant as influenced by INM on Italian aster (Aster amellus L.) cv. 'Purple Multipetal' at different stages of growth

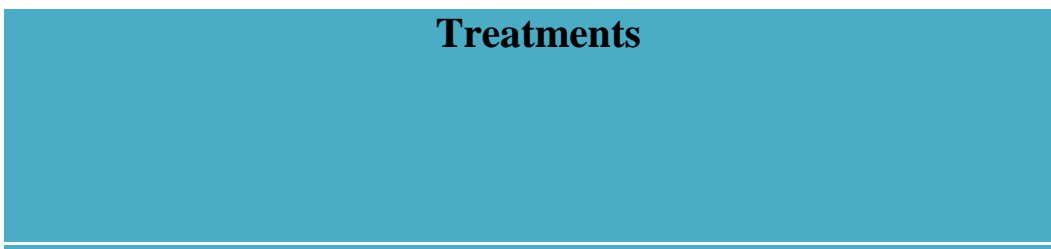

$\mathrm{T}_{1}=100 \% \mathrm{RDF}$

$\mathrm{T}_{2}=\mathrm{RDF} 50 \%+\mathrm{RDF} 50 \%$ through VC

$\mathrm{T}_{3}=\mathrm{RDF} 50 \%+\mathrm{RDF} 50 \%$ through $\mathrm{VC}+\mathrm{Azo}$

$\mathrm{T}_{4}=\mathrm{RDF} 50 \%+\mathrm{RDF} 50 \%$ through $\mathrm{VC}+\mathrm{PSB}$

$\mathrm{T}_{5}=\mathrm{RDF} 50 \%+$ RDF $50 \%$ through FYM

$\mathrm{T}_{6}=\mathrm{RDF} 50 \%+\mathrm{RDF} 50 \%$ through FYM + PSB

$\mathrm{T}_{7}=\mathrm{RDF} 50 \%+\mathrm{RDF} 50 \%$ through VC $+\mathrm{Azo}+\mathrm{PSB}$

$\mathrm{T}_{8}=\mathrm{RDF} 50 \%+\mathrm{RDF} 50 \%$ through FYM + Azo + PSB

Mean

S.Em \pm

CD at $5 \%$

Where,

DAP: Days after planting

Azo: Azospirillum sp.

PSB: Phosphate solubilizing bacterium

RDF: Recommended dose of Fertilizers.

\begin{tabular}{|c|c|c|c|}
\hline \multicolumn{4}{|c}{ No. of leaves per plant } \\
\hline DAP & 60 & 90 & 120 \\
DAP & DAP & DAP \\
\hline 13.40 & 38.4 & 70.66 & 175.8 \\
\hline 11.86 & 33.6 & 60.8 & 160.26 \\
\hline 12.46 & 35.13 & 65.06 & 168.06 \\
\hline 13.13 & 36.46 & 68.26 & 170.53 \\
\hline 10.53 & 30.8 & 58.93 & 151.6 \\
\hline 12.76 & 34.26 & 63.93 & 165.26 \\
\hline 15.20 & 45.06 & 81.20 & 198.06 \\
\hline 14.26 & 40.8 & 75.33 & 180.2 \\
\hline 12.95 & 36.81 & 68.02 & 171.22 \\
\hline 0.34 & 0.48 & 0.58 & 0.58 \\
\hline 1.04 & 1.47 & 1.77 & 1.76 \\
\hline & & & \\
\hline
\end{tabular}

FYM: Farm Yard Manure

VC: Vermicompost 
Table.2 Plant height $(\mathrm{cm})$, plant spread $(\mathrm{cm})$ E-W, plant spread $(\mathrm{cm}) \mathrm{N}-\mathrm{S}$ and No. of suckers per plantas influenced by INM on Italian aster (Aster amellus L.) cv. 'Purple Multipetal' at different stages of growth

\begin{tabular}{|c|c|c|c|c|c|c|c|c|c|c|c|c|c|c|c|}
\hline \multirow[t]{2}{*}{ Treatments } & \multicolumn{4}{|c|}{ Plant height (cm) } & \multicolumn{4}{|c|}{ Plant spread (cm) E-W } & \multicolumn{4}{|c|}{ Plant spread $(\mathrm{cm}) \mathrm{N}-\mathrm{S}$} & \multicolumn{3}{|c|}{$\begin{array}{l}\text { No. of suckers per } \\
\text { plant }\end{array}$} \\
\hline & $\begin{array}{c}30 \\
\text { DAP }\end{array}$ & $\begin{array}{c}\text { 60 } \\
\text { DAP }\end{array}$ & $\begin{array}{c}90 \\
\text { DAP }\end{array}$ & $\begin{array}{c}120 \\
\text { DAP }\end{array}$ & $\begin{array}{c}30 \\
\text { DAP }\end{array}$ & $\begin{array}{c}60 \\
\text { DAP }\end{array}$ & $\begin{array}{c}90 \\
\text { DAP }\end{array}$ & $\begin{array}{c}120 \\
\text { DAP }\end{array}$ & $\begin{array}{c}30 \\
\text { DAP }\end{array}$ & $\begin{array}{c}\text { 60 } \\
\text { DAP }\end{array}$ & $\begin{array}{c}90 \\
\text { DAP }\end{array}$ & $\begin{array}{c}120 \\
\text { DAP }\end{array}$ & $\begin{array}{c}\text { 60 } \\
\text { DAP }\end{array}$ & $\begin{array}{c}90 \\
\text { DAP }\end{array}$ & $\begin{array}{r}120 \\
\text { DAP }\end{array}$ \\
\hline $\mathrm{T}_{1}=100 \% \mathrm{RDF}$ & 16.63 & 27.31 & 44.79 & 56.58 & 14.16 & 25.23 & 26.76 & 31.03 & 13.23 & 26.06 & 27.70 & 32.66 & 3.86 & 8.50 & $\begin{array}{c}13.2 \\
3\end{array}$ \\
\hline $\mathrm{T}_{2}=\mathrm{RDF} 50 \%+\mathrm{RDF} 50 \%$ through VC & 14.83 & 20.33 & 29.47 & 42.08 & 10.33 & 20.30 & 22.10 & 25.06 & 9.50 & 21.13 & 24.36 & 28.36 & 1.10 & 7.13 & $\begin{array}{c}10.7 \\
0\end{array}$ \\
\hline $\begin{array}{l}\mathrm{T}_{3}=\mathrm{RDF} 50 \%+\mathrm{RDF} 50 \% \text { through VC } \\
+\mathrm{Azo}\end{array}$ & 15.46 & 23.43 & 34.73 & 48.00 & 11.01 & 21.40 & 23.23 & 26.40 & 10.16 & 22.40 & 25.10 & 29.50 & 1.36 & 7.60 & $\begin{array}{c}11.8 \\
0\end{array}$ \\
\hline $\begin{array}{l}\mathrm{T}_{4}=\mathrm{RDF} 50 \%+\mathrm{RDF} 50 \% \text { through VC } \\
+ \text { PSB }\end{array}$ & 16.33 & 25.76 & 40.30 & 54.33 & 12.16 & 24.10 & 26.30 & 29.20 & 11.13 & 24.93 & 27.16 & 31.30 & 3.26 & 8.66 & $\begin{array}{c}12.8 \\
0\end{array}$ \\
\hline $\begin{array}{l}\mathrm{T}_{5}=\mathrm{RDF} 50 \%+\text { RDF } 50 \% \text { through } \\
\text { FYM }\end{array}$ & 13.43 & 17.46 & 28.25 & 37.33 & 9.33 & 18.60 & 19.43 & 24.13 & 8.50 & 19.40 & 22.53 & 27.50 & 1.16 & 6.50 & $\begin{array}{c}10.0 \\
6\end{array}$ \\
\hline $\begin{array}{l}\text { T }_{6}=\text { RDF } 50 \%+\text { RDF } 50 \% \text { through } \\
\text { FYM + PSB }\end{array}$ & 16.20 & 23.00 & 38.16 & 50.33 & 12.01 & 23.16 & 25.45 & 27.80 & 11.01 & 24.03 & 26.30 & 30.86 & 2.20 & 8.40 & $\begin{array}{c}12.5 \\
6\end{array}$ \\
\hline $\begin{array}{l}\mathrm{T}_{7}=\mathrm{RDF} 50 \%+\mathrm{RDF} 50 \% \text { through } \\
\mathrm{VC}+\mathrm{Azo}+\mathrm{PSB}\end{array}$ & 18.36 & 32.20 & 52.16 & 64.25 & 17.23 & 28.36 & 30.52 & 34.30 & 16.23 & 29.20 & 31.33 & 36.43 & 6.33 & 10.16 & $\begin{array}{c}15.4 \\
6\end{array}$ \\
\hline $\begin{array}{l}\text { T }_{8}=\text { RDF } 50 \%+\text { RDF } 50 \% \text { through } \\
\text { FYM + Azo + PSB }\end{array}$ & 17.43 & 29.72 & 47.16 & 58.36 & 15.16 & 26.13 & 28.37 & 32.45 & 14.33 & 26.63 & 29.46 & 33.40 & 4.53 & 9.60 & $\begin{array}{c}14.3 \\
6\end{array}$ \\
\hline Mean & 16.08 & 24.90 & 39.38 & 51.41 & 12.67 & 23.41 & 25.27 & 28.79 & 11.76 & 24.22 & 26.74 & 31.25 & 2.97 & 8.32 & $\begin{array}{c}12.6 \\
2\end{array}$ \\
\hline S.Em \pm & 0.34 & 0.75 & 0.40 & 1.50 & 0.57 & 0.68 & 0.53 & 0.47 & 0.55 & 0.65 & 0.57 & 0.63 & 0.36 & 0.35 & 0.33 \\
\hline CD at $5 \%$ & 1.02 & 2.27 & 1.20 & 4.54 & 1.72 & 2.07 & 1.60 & 1.43 & 1.69 & 1.97 & 1.73 & 1.92 & 1.09 & 1.08 & 1.02 \\
\hline
\end{tabular}


Table.3 Flowering and yield parameters as influenced by INM on Italian aster (Aster amellus L.) cv. 'Purple Multipetal'

\begin{tabular}{|c|c|c|c|c|c|c|c|c|}
\hline Treatments & $\begin{array}{l}\text { Days } \\
\text { taken to } \\
\text { flower } \\
\text { bud } \\
\text { initiation }\end{array}$ & $\begin{array}{c}\text { Days } \\
\text { taken to } \\
50 \\
\text { percent } \\
\text { flowering }\end{array}$ & $\begin{array}{l}\text { Number of } \\
\text { flowers per } \\
\text { plant }\end{array}$ & $\begin{array}{c}\text { Number } \\
\text { of } \\
\text { flowers } \\
\text { per } \\
\text { spike }\end{array}$ & $\begin{array}{c}\text { Number } \\
\text { of } \\
\text { spikelets } \\
\text { per } \\
\text { spike }\end{array}$ & $\begin{array}{c}\text { Number } \\
\text { of flower } \\
\text { spikes } \\
\text { per } \\
\text { plant }\end{array}$ & $\begin{array}{l}\text { Number } \\
\text { of flower } \\
\text { spikes } \\
\text { per plot }\end{array}$ & $\begin{array}{l}\text { Spike no. } \\
\text { per ha. } \\
\text { (in lakhs) }\end{array}$ \\
\hline $\mathrm{T}_{1}=100 \% \mathrm{RDF}$ & 74.8 & 86.83 & 267.86 & 153.33 & 30.33 & 3.90 & 97.50 & 4.33 \\
\hline $\mathrm{T}_{2}=\mathrm{RDF} 50 \%+\mathrm{RDF} 50 \%$ through VC & 81.66 & 93.66 & 194.86 & 114.66 & 25.26 & 2.26 & 56.66 & 2.69 \\
\hline $\mathrm{T}_{3}=\mathrm{RDF} 50 \%+\mathrm{RDF} 50 \%$ through $\mathrm{VC}+\mathrm{Azo}$ & 79.73 & 91.90 & 241.46 & 117.00 & 28.23 & 2.43 & 60.83 & 2.73 \\
\hline $\mathrm{T}_{4}=\mathrm{RDF} 50 \%+\mathrm{RDF} 50 \%$ through VC + PSB & 75.73 & 87.73 & 252.2 & 130.01 & 28.20 & 3.20 & 80.00 & 3.55 \\
\hline $\mathrm{T}_{5}=\mathrm{RDF} 50 \%+$ RDF $50 \%$ through FYM & 82.86 & 94.90 & 185.86 & 104.33 & 24.06 & 2.06 & 51.66 & 2.29 \\
\hline $\begin{array}{l}\text { T }_{6}=\text { RDF 50\% + RDF 50\% through FYM + } \\
\text { PSB }\end{array}$ & 76.93 & 88.86 & 251.8 & 121.66 & 28.16 & 3.03 & 75.83 & 3.36 \\
\hline $\begin{array}{l}\mathrm{T}_{7}=\mathrm{RDF} 50 \%+\mathrm{RDF} 50 \% \text { through } \mathrm{VC}+\mathrm{Azo} \\
+ \text { PSB }\end{array}$ & 69.66 & 81.73 & 30.33 & 181.00 & 35.20 & 4.20 & 105.00 & 4.66 \\
\hline $\begin{array}{l}\mathrm{T}_{8}=\mathrm{RDF} 50 \%+\mathrm{RDF} 50 \% \text { through FYM }+ \\
\mathrm{Azo}+\mathrm{PSB}\end{array}$ & 72.73 & 84.83 & 284.33 & 164.00 & 32.90 & 4.06 & 101.66 & 4.51 \\
\hline Mean & 76.76 & 88.80 & 247.34 & 135.75 & 29.04 & 3.14 & 78.64 & 3.51 \\
\hline S.Em \pm & 0.50 & 0.48 & 1.63 & 5.30 & 0.52 & 0.02 & 0.69 & 0.08 \\
\hline CD at $5 \%$ & 1.51 & 1.46 & 4.93 & 16.00 & 1.57 & 0.08 & 2.09 & 0.25 \\
\hline
\end{tabular}

Where, DAP: Days after planting, FYM: Farm Yard Manure, Azo: Azospirillum sp., PSB: Phosphate solubilizing bacterium, RDF: Recommended dose of Fertilizers, VC: Vermicompost 
Significant variations were observed among different combinations of inorganic, organic and bio fertilizers application with respect to floral parameters, minimum number of days (69.66 days) taken to flower bud initiation and 50 per cent flowering (81.73 days) and Maximum number of flowers per plant (300.33), number of flowers per spike (181.00) was recorded in $\mathrm{T}_{7}$ (RDF $50 \%+$ RDF 50\% through VC + Azo + PSB). Maximum number of days (82.86 days) taken to flower bud initiation and 50 per cent flowering (94.90 days) and minimum number of flowers per plant (185.86), number of flowers per spike (104.33)was recorded in $\mathrm{T}_{5}$ (RDF $50 \%$ + RDF $50 \%$ through FYM).

Maximum number of spikelets per spike (35.20), number of flower spikes per plant (4.20), number of flower spikes per plot (105.00), number of flower spikes per ha. (4.66 lakhs) was recorded in $\mathrm{T}_{7}$ (RDF $50 \%+$ RDF $50 \%$ through VC + Azo + PSB). While, minimum number of spikelets per spike (24.06), number of flower spikes per plant (2.06), number of flower spikes per plot (51.66), number of flower spikes per ha. (2.29 lakhs) was recorded in $\mathrm{T}_{5}$ (RDF $50 \%+\mathrm{RDF}$ $50 \%$ through FYM) (Table 3).

The increase in number of flower spikes might be due to possible role of Azospirillum through atmospheric nitrogen fixation, better root proliferation, uptake of nutrients and water. More photosynthesis enhanced food accumulation which might have resulted in better growth and subsequently higher number of flower spikes per plant and hence, more number of flower yield per hectare. Besides this, increase in flower spike yield may be attributed to increased availability of phosphorus and its greater uptake by PSB (Kundu and Gaur, 1980). Further vermicompost, as the source of macro and micro nutrients like $\mathrm{Fe}$ and $\mathrm{Zn}$, enzymes, growth hormones and beneficial effects of micro flora might have played a secondary role in increasing the flower spike yield. These results are in line with the findings Akter et al., (2017) in gladiolus, Sunita Kumari and VM Prasad (2017) in petunia, Swati et al., (2017) in golden rod and Ghisewad et al., (2016) in gladiolus.

On the basis of results obtained in the present investigation, it can be concluded that the application inorganic fertilizers, organic manures along with inoculation of Azospirillum and PSB results in higher flower yield in Italian aster. Therefore application of RDF $50 \%$ through inorganic $+50 \%$ through $\mathrm{VC}+\mathrm{Azo}+\mathrm{PSB}\left(\mathrm{T}_{7}\right)$ recorded better plant growth, flowering and higher yield in Italian aster (Aster amellus L.) cv. 'Purple Multipetal'.

\section{References}

Abhinav Kumar and Ashok Kumar. 2017. Effect of bio-fertilizers and nutrients on growth and flower yield of summer season African marigold (Tagetes erecta L.) Plant Archives Vol. 17 No. 2, 2017 pp. 1090-1092.

Akter, N., Ara, K.A., Akand, M.H. and Alam, M.K. 2017. Vermicompost and trichocompost in combination with inorganic fertilizers increased growth, flowering and yield of gladiolus cultivar (gl-031) (Gladiolus grandiflorus L.) Advances in Research 12(3): 1-11, 2017; Article no.AIR.37034.

Anamika Gurung., Gupta, Y.C., Suman, B., Priyanka Thakur and Priya Yadav. 2018. Effect of integrated nutrient management on growth and production of Hydrangea (Hydrangea macrophylla Thunb.). Int.J.Curr.Microbiol.App.Sci. $\quad 7(04)$ : 2080-2086.

Anand, M., Sankari, A. And Arulmozhiyan, R. 2016. Effect of integrated nutrient management in Cymbidium giganteum under Shevaroy condition.The bio scan; 11(1): 439-443, 2016. 
Angadi and Airadevi, P. 2014. Effect of integrated nutrient management on yield, economics and nutrient uptake of garland chrysanthemum

(Chrysanthemum coronarium L.). Asian J. Hort., 9(1): 132135.

Anonymous. 2017. All India area and production of flowers. National Horticulture data base.www.nhb.gov.in

Arab Azam, Gholam, R. Z., Mohammad, H. S. and Javad Asili. 2015 Effects biological fertilizers on morpho-physiological traits of marigold (Calendula officinalis L.) European Journal of Medicinal Plants 8(1): 60-68,

Basavaraj, D. and Hemla Naik, B. 2014.Integrated nutrient management studies in carnation (Dianthus caryophyllus L.) Cv. Soto under protected condition. Vol. 2, No. 3.

Bellubbi, S. B., Kulkarni, B. S. and Patil, C. P. 2015. Effect of integrated nutrient management on growth and flowering of gerbera (Gerbera jamesonii L.) var. Rosalin under naturally ventilated polyhouse condition. International of Agriculture Science and Veterinary Medicine, 1(1):69-74.

Chaudhary, N., Swaroop, K., Janakiram, T., Biswas, D.R. and Singh, G. 2013. Effect of integrated nutrient management on vegetative growth and flowering characters of gladiolus. Indian Journal of Horticulture, 70(1): 156-159.

Dhanumjaya Rao, K., Lalitha Kameswari, P., and Baby Rani, T. 2014, Impact of integrated nutrient management on growth, flowering, yield and economics of Tuberose. Agricultural Research Communication Centre. DOI: 10.5958/0976-0547.2015.00014.2.

Gangadharan, G.D. and Gopinath, G. 2000. Effect of organic and inorganic fertilizers on growth, flowering and quality of gladiolus Cv. White prosperity. Karnataka Journal of Agricultural Sciences. 13: 2 401-405.

Geeta, B.L., Siddappa, Mahadevamma, M., Likitha Raj and Manjunath Totad. 2016.
Influence of NPK and bio fertilizers on growth, yield and quality of China aster (Callistephus chinensis (L.) Nees) for cut flower production. Research in Environment and Life Sciences. 9(10): 1236-1238.

Ghisewad, S.K., Sable, P.B. and Rohidas, S.B. 2016. Effect of organic and inorganic fertilizers on growth and flower quality of gladiolus Cv. H.B. Pitt. Asian J. Hort., 11(2): 275-279.

Hadwani, K., Mayuri, Varu, D.K., Panjiar, Niketa and Babariya, V.J. 2013. Effect of integrated nutrient management on growth, yield and quality of ratoon tuberose (Polianthes tuberose L.) cv. Double. Asian J. Hort., 8(2): 448-451.

Harish, S., Doddujjappalavar, Hemla Naik, B., Chandrashekar, S.Y., Nandeesh, M.S. and Kantharaj, Y. 2018. Enhanced flower yield and quality attributes of Chrysanthemum (Dendranthema grandiflora Tzvelev) inoculated with phosphorus solubilizing and mobilizing bioinoculants at different levels of phosphorus. Int.J.Curr.Microbiol.App. Sci. 7(04): 1821-1827.

Harshavardhan, M. D., Kumar, P., Rajesh, A M., Yathindra, H. A. and Shivanand Hongal. 2016. Growth and development of carnation (Dianthus caryophyllus L.) as influenced by integrated nutrient management. The bio scan; 11(4): 26912694.

Jackson, M. L. 1967. Soil chemical analysis. Prentice Hall of India Pvt. Ltd., New Delhi, pp. 183-192.

Jambhekar, H. A. 1992. Use of earthworm as a potential source to decompose organic waste. In: Proceedings of national seminar on organic farming, MPKV, Pune, pp. 52-53.

Karuppaiah, P. 2005. Effect of Azospirillum, phosphobacteria and organic manures on growth and yield of French marigold (Tagetes patula L.). Plant Archives 5: 2, 661-664.

Kaushik, H., Singh, J. P., Mohan, B., Rajbeer and Nathiram. 2013. Effect of inorganic 
fertilizer and bio fertilizer on growth and flowering in African marigold (Tagetus erecta L.) Cv. Pusa Narangi Gainda. Internat. J. agric. Sci., 9(1):189-192.

Kund, and Gaur, A.C. 1980. Phosphorous Solubilizing Microorganisms as BioFertilizers, Omega Scientific Publishers, New Delhi, pp. 63-90.

Laishram, N., Dhiman, S.R., Gupta, Y.C., Bhardwaj, S.K and Singh, A. 2013. Microbial dynamics and physic chemical properties of soil in the rhizosphere of chrysanthemum

(Dendranthema grandiflora) as influenced by integrated nutrient management. Indian J. of Ag. Sci. 83(4): 447-455.

Mahadik, M.K., Dalal, S.R., Disha, A., Patil and Wararkar, S.M. 2017.Nutritional and economic studies in chrysanthemum $\mathrm{Cv}$. PDKV Ragini. Journal of Pharmacognosy and Phytochemistry; 6(5): 2646-2650.

Mamta, S.K., Khandelwal, M.R., Choudhary, P.K., Kumawat, G., Sharma and Paru Panwar. 2017. Effect of integrated nutrient management on growth, flowering and yield of African marigold (Tagetes erecta L.). Int.J.Curr.Microbiol. App.Sci. 6(8): 60-65.

Mridubhashini, P., Gaurav Sharma., Chetna Banjare., Deepika Chandravanshi and Eshu Sahu. 2014. Effect of integrated nutrient management on the growth, development and yield of Chrysanthemum. The ecoscan.6: 459-462.

Muthamizhselvi, M., Arulmozhiyan, R., Jawaharlal, M. and Mani, S. 2006. Integrated nutrient management on nutrient content of leaves and uptake in chrysanthemum

(Dendranthema grandiflora Tzelev.) cv. Co.1. S. Ind. Hort., 54 (1-6): 318-322.

Nagalakshmi, S., Sankri, A., Anand, M., and Arulmozhiyan, R. 2010. Organic stimulants on the growth and yield of anthurium (Anthurium andreaum) $\mathrm{Cv}$. Verdun Red. Asian Journal of Horticulture, 5(2):450-452.
Naik, M. R. 2015. Influence of bio fertilizers on growth, flowering and yield of African marigold $\mathrm{Cv}$. Orange Bunch. Indian Horticulture Journal, 5(3):78-81.

Narasimha, S. and Haripriya, K. 2001. Integrated nutrient management in crossandra (Crossandra infundibuliformis L.) Cv. Dindigul local. South Indian Hort., 49: 181-184.

Neha, C., Siddhi, P., Ommala, K., and Raut, V.U. 2017. Growth, yield and quality of Jasmine vary by integrated plant nutrition. Journal of Pharmacognosy and Phytochemistry; 6(6): 1201-1203.

Palagani, Neelima, Barad, A.V., Bhosale and Thumar, B.V., 2013. Influence of integrated plant nutrition on growth and flower yield of Chrysanthemum (Chrysanthemum morifolium Ramat.) cv. IIHR-6 under Saurashtra condition. Asian J. Hort., 8(2): 502-506.

Panse, V.S. and Sukhtme, P.V. 1985. Statistical methods for agricultural workers. Indian council of Agricultural Research New Delhi, 152-155.

Pansuriya, P.B. and Chauhan, R.V. 2015. Effect of integrated nutrient management on growth, yield and quality of gladiolus (Gladiolus grandifloru L.) Cv. Psittacinus Hybrid. J. Horticulture 2: 129. doi:10.4172/2376-0354.1000129.

Patel, V.S., Malam, V.R., Nurbhanej, K.H., Vihol, A.N. and Chavada, J.R., 2017. Effect of organic manures and biofertilizers on growth, flowering and flower yield of Rose (Rosa hybrida L.) cv. Gladiator. International Journal of Chemical Studies; 5(5): 1924-1927.

Path, S.R., Reddy, B.S. and Prasanth, J.M., 2004. Effect of organic, inorganic and in stiu vermiculture on chlorophyll content and flower yield of Jasminum sambac Ait. J. Orn. Hort., 7 (3-4): 164-167.

Prashant, S.S., Prakash, Mukesh, K., Sunil, M. and Arvind Kumar. 2015. Effect of integrated nutrient management (INM) on growth, flowering and yield in Mari gold (Tagetus erectaL.) cv. "Pusa Basanti" Annals of Horticulture 8 (1): 73-80. 
Rajesh Khanna, P., Mamta, B., Parul, P. and Nautiyal, B.P. 2016. Studies on the effect of organic manures and PSB on vegetative and floral parameters of China aster (Callistephus chinensis (L.) Ness.) $\mathrm{Cv}$. Kamini under mid Hills region of Himalaya. The bio scan.11 (4): 27072710

Rajesh, B., Sandeep, D., Dhiman, S. R. and Ritu, J. 2006. Effect of biofertilizers and biostimulants on growth and flowering in standard carnation (Dianthus Caryophyllus Linn.) Journal of Ornamental Horticulture, 9 (4): 282-284.

Ranchana, P. And Ganga, M. 2017. Integrated nutrient management in orchid (Dendrobium spp.) cv. Sonia 17. 12(2): The bio scan.1057-1059.

Rao, M.R., Rego, T.J. and Wiley, R.W. 1987. Response of cereal to nitrogen in sole cropping and intercropping with different legumes. Plant and Soils, 101: 167-177.

Rekha, M.K., Shankaraiah, V., Reddy, K.C., Srihari, D. and Sarma, P.S. 2001. Effect of preservative solutions with sucrose on vase life of cut gladiolus spikes at room temperature. Journal of Research ANGRAU 29(2):44-49.

Rokolhuii, K., 2012. Response of Gerbera to inorganic fertilization versus organic manuring. Ann. Pl. Soil Res. 14(2):163166 (2012).

Rolaniya, Khandelwal, S.K., Choudhary, A. and Priynka, K. 2013. Response of African marigold to NPK, biofertilizers and spacings. Journal of Applied and Natural Science 9 (1): 593 - 597 (2017).

Rubina, K., Dipa, K. and Patra, S.K. 2017. Effect of integrated nutrient management on growth, quality, yield and soil fertility of gladiolus in lower gangetic plain of India. Int.J.Curr.Microbiol.App.Sci. 6(4): 453-459.

Satapathy, S.P., Toppo, R., Dishri, M. and Mohanty, C.R. 2016. Impact of integrated nutrient management on flowering and corm production in Gladiolus. Biostat Int. J. 4(7): 00119. DOI: 10.15406/bbij.2016. 04.00119 .
Sathyanarayana, E., Sudha, P. and Chawla, S.L. 2017. Impact of integrated nutrient management on growth and flowering of gladiolus (Gladiolus grandiflorus L.) cv. American beauty. International Journal of Chemical Studies; 5(5): 317-319.

Satish Kumar, P., Prasad, V.M. Vivek Kumar, Madhur Kumar and Saravanan. S. 2018. Effect of bio fertilizers and inorganic manures on plant growth and flowering of chrysanthemum (Chrysanthemum grandiflora) cv. Haldighati. Journal of Pharmacognosy and Phytochemistry, SP1: 637-642.

Satish, K.P., Supriya, K., Digendra, S., Vivek, K.S. and Prasad, V.M. 2017. Effect of biofertilizers and organic manures on plant growth, flowering and tuber production of Dahlia (Dahlia variabilis L.) cv. S.P. Kamala. Int. J. Pure App. Biosci. 5 (2): 549-555.

Sattar, M.A. and Gaur, A.C. 1987. Production of auxins and gibberellins by phosphate dissolving mcrooganisms. Zentralbl Microbiol., 142: 393-395

Sharma, G., Naresh, P.S. and Neeraj, S., 2016. Effect of bio-organic and inorganic nutrient sources on growth and flower production of African marigold. Horticulturae, $\quad 3, \quad 11$; doi:10.3390/horticulturae3010011.

Shivaraj, K. 2010. Integrated nutrient management studies in Chrysanthemum (Chrysanthemum morifolium Ramat.) cv. Raja. M.sc (Ag).Thesis, University of Agricultural Sciences, Dharwad.

Siddappa. 2017. Studies on varietal response of Italian aster (Aster amellus L.) to different plant spacings and postharvest vase life under Southern Telangana conditions. M.Sc. Thesis, Sri Konda Laxman Telangana State Horticultural University, college of horticulture, Rajendranagar, HYD.

Singh, R., Mukesh, K., Sameeksha, R. and Sanjay, K. 2014. Flowering and corm production in gladiolus (Gladiolus grandiflorus L.) Cv. "White Prosperity" as influenced by integrated nutrient 
management (INM). Annals of Horticulture 7(1): 36-42.

Subbaiah, B. V. and Asija, G. L. 1956. A rapid procedure for the estimation of available nitrogen in soils. Curr. Sci., 25: 259.

Sunita, K. and Prasad, V.M. 2017. Studied effect of bio and chemical fertilizers on plant growth and yield of petunia (Petunia hybrida) var. Picotee. International Journal of Chemical Studies; 5(4): 1251-1254.

Swati, P., Patel, R.B., Chawla, S.L., Dipal, B. and Khyati, P. 2017. Effect of chemical and bio fertilizers on growth and flowering of Golden rod (Solidago canadensis L.) Cv. "Local". International Journal of Chemical Studies; 5(5): 104108.

Thakur, R., Dubey, R.K., Kukal, S.S. and Kapoor, S. 2016. Interactive effect of biofertilizers and organic potting media on growth and flowering of calendula (Calendula officinalis Linn.). Indian Journal of Ecology, 43(1):245-248.

Vaishali, P., Patel, G.D., Desai, K.D., Maitri, D. and Unnati Patel. 2017. Integrated nutrient management in African marigold (Tagetes erecta L.). International Journal of Chemical Studies; 5(4): 1352-1354.

Vasantha, K.R., Kumar, D.P., Mahadevamma, M. and Arunkumar, B. 2013. Effect of integrated nutrient management on growth and floral parameters in gladiolus (Gladiolus hybridus L) cv. American Beauty, Asian J. Hort., 8(1): 274-279.

Venkatarayappa, T., Tsuita, M.J. and Nurr, D.P., 1980. Influence of cobaltous ion $\left(\mathrm{CO}^{+2}\right)$ on the post-harvest behavior of 'Samantha' roses. Journal of American society for Horticultural sciences.105:148-151.

Verma, S.K., Angadi, S.G., Patil, V.S., Mokashi, A.N., Mathad, J.C. and Mummigatti, U.V., 2011. Growth, yield and quality of chrysanthemum (Chrysanthemum morifolium Ramat.) cv. Raja as influenced by integrated nutrient nmanagement. Karnataka J. Agricultural Sciences. 24(5): 681-683.

Yadav, K.S., Pal, A.K., Singh, A.K., Yadav, D. and Mauriya, S.K. 2017. Influence of different bio fertilizers and its consortium on growth, flowering and seed yield of Marigold, Int. J. Pure App. Biosci. 5(6):1660-1665.

Yathindra, H.A., Krishna, M.R., Rajesh, A.M. and Harshavardhan, M. 2016. Effect of integrated nutrient management (INM) on growth parameters of Bird of Paradise (Strelitzia reginae (L.))". The bio scan 11(1): 565-568.

\section{How to cite this article:}

Krushnaiah, R., M. Hanuman Nayak, P. Prasanth and Saidanaik, D. 2018. Studies on the Effect of Integrated Nutrient Management on Growth, Flowering and Yield of Italian Aster (Aster amellus L.) cv. 'Purple Multipetal'. Int.J.Curr.Microbiol.App.Sci. 7(10): 936-946. doi: https://doi.org/10.20546/ijcmas.2018.710.104 